\title{
Apakah Anda Merasa Kesepian? Eksplorasi Kepribadian dan Kualitas Pertemanan pada Remaja
}

\author{
Fikrie, Ceria Hermina, Lita Ariani \\ Universitas Muhammadiyah Banjarmasin
}

\begin{abstract}
This study examined the role of hardiness, friendship quality, and loneliness on first-year college students. 333 participants completed three scales: hardiness scale, friendship quality scale, and loneliness scale. A multiple linear regression test was used with hardiness and friendship quality as an independent variable and loneliness as a dependent variable. The result showed that hardiness and friendship quality simultaneously were significant predictors of loneliness $(F=101,03 ; p<, 001)$. Loneliness variance was explained by both hardiness and friendship quality of $38 \%(R 2=, 38)$. When given separately, hardiness was significant predictor to loneliness with variance explained of $26,22 \%(R 2=, 2622 ; p<, 001)$ and friendship quality was significant predictor to loneliness with variance explained of $11,25 \%(R 2=, 1125$; $p<, 001)$. It can be concluded that improving the hardiness and friendship quality of the first-year college students will lead them to reduce loneliness.
\end{abstract}

Keyword: Friendship Quality; Hardiness; Loneliness

\begin{abstract}
Abstrak
Penelitian ini bertujuan untuk menguji peran hardiness, kualitas pertemanan dan kesepian pada mahasiswa tahun pertama perkuliahan. Terdapat 333 subjek penelitian yang mengisi tiga skala yaitu skala hardiness, skala kualitas pertemanan dan skala kesepian. Analisis data menggunakan regresi liniear berganda dengan hardiness dan kualitas pertemanan sebagai variabel bebas dan kesepian variabel terikat. Hasil meunjukkan bahwa hardiness dan kualitas pertemanan secara bersama signifikan memprediksi kesepian $(F=101,03 ; p<, 001)$. Variasi kesepian dapat dijelaskan sebesar $38 \%$ oleh hardiness dan kualitas pertemanan $\left(\mathrm{R}^{2}=, 38\right)$. Secara parsial, hardiness signifikan memprediksi kesepian dengan variasi sebesar 26,22\% demikian juga kualitas pertemanan signifikan memprediksi kesepian dengan variasi sebesar 11,25\% $\left(\mathrm{R}^{2}=\right.$ ,1125; $\mathrm{p}<, 001)$. Dapat disimpukan bahwa dengan meningkatkan hardiness dan kualitas pertemanan pada mahasiswa tahun pertama perkuliahan dapat menurunkan kesepian.
\end{abstract}

Kata Kunci : Kualitas Pertemanan; Hardiness; Kesepian

Kebutuhan berafiliasi atau kebutuhan untuk berinteraksi dengan orang lain merupakan kebutuhan dasar yang ada dalam diri manusia, tak terkecuali pada fase usia remaja. Kebutuhan ini berperan penting bagi remaja terutama terkait dengan tugas perkembangan yang harus 
mereka penuhi yaitu pencarian identitas diri, sebuah proses eksplorasi siapa diri mereka dan bagaiamana mereka menyesuaikan diri dengan lingkungan (Benner, 2011). Untuk memenuhi kebutuhan ini remaja memerlukan penerimaan dari lingkungan tetapi pada kenyataannya tidak setiap saat remaja mendapatkan penerimaan dari lingkungan sekitar mereka (Benner, 2011).

Kebutuhan ini juga diperlukan oleh mahasiswa tahun pertama perkuliahan. Tahun pertama perkuliahan merupakan masa transisi perubahan rasa keterhubungan dan keamanan yang telah didapatkan dari keluarga dan komunitas mereka sebelumnya menjadi kebutuhan membangun keterhubungan dan identitas di lingkungan baru (Asher \& Weeks, 2013). Jauh dari orangtua, tanggung jawab terhadap sistem akademik baru, mencari teman, sahabat dan menemukan cara untuk menjadi anggota di lingkungan baru adalah beberapa tantangan dan kesulitan yang harus di hadapi oleh mahasiswa tahun pertama(Asher \& Weeks, 2013; Hicks \& Heastie, 2008; Smith \& Wertlieb, 2011). Mahasiswa yang berhasil melewati kesulitan dan tantangan tersebut mengembangkan keterampilan, kompetensi dan pengetahuan diri yang berguna untuk membantu mereka melakukan penyesuaian pada masa transisi ini (Asher \& Weeks, 2013), sebaliknya ketika mereka tidak mampu menghadapinya maka dapat memicu pengalaman kesepian pada diri mereka (Lou et al., 2012).

Kesepian adalah pengalaman subjektif yang tidak menyenangkan dimana seseorang merasakan adanya perbedaan hubungan sosial di komunitasnya. Perbedaan yang dimaksud adalah ketidaksesuaian keinginan dengan apa yang dirasakan baik secara kualitas maupun kuantitas dalam hal hubungan sosial di komunitasnya (Asher \& Weeks, 2013). Tidak mampu menjalin hubungan dekat, memiliki sedikit teman, merasa frustasi, tidak puas dan menurunnya intensitas dalam suatu hubungan pertemanan adalah beberapa fenomena kesepian yang sering terjadi (Olenik-Shemesh et al., 2012). Menurut Shemesha, Heimana dan Eden, Pengalaman kesepian dapat termanifestasi dalam bentuk ketidakmampuan menjalin hubungan dekat, memiliki sedikit teman, merasa frustasi dan tidak puas dengan sebuah hubungan, kurang tertarik mengembangkan hubungan sosial dan menurunnya intensitas dalam hubungan persahabatan (Fikrie \& Hermina, n.d.). Kesepian merupakan pengalaman sementara tanpa adanya konsekuensi negatif yang bertahan lama, tetapi bagi sebagian orang kesepian merupakan pengalaman yang menyakitkan dan berkepanjangan serta berefek pada kesehatan 
mental dan fisik (Qualter et al., 2015). Kesepian, biasanya ditandai dengan perasaan negatif seperti kesedihan dan pesimis (Wols et al., 2015).

Bagi sebagian orang kesepian merupakan pengalaman yang menyakitkan dan berkepanjangan serta berefek pada kesehatan mental dan fisik (Qualter et al., 2015). Kesepian bisa dialami oleh semua orang dalam variasi usia, tetapi sebagian besar dialami oleh remaja, secara spesifik remaja yang berada pada rentang usia 12-22 tahun dan 20-50 \% remaja pada umumnya mengalami kesepian (Kapıkıran, 2013; Rönkä et al., 2014). Hal ini disebakan karena kebutuhan akan penerimaan dan keakraban dengan teman sebaya menjadi sangat penting pada fase ini (Acquah et al., 2016; Kapıkıran, 2013), remaja yang diabaikan dan dipandang negatif oleh teman sebayanya cenderung merasa kesepian dan terisolasi secara sosial (Kapıkıran, 2013). Kesepian memberikan dampak negatif kepada remaja antara lain cenderung memiliki keterampilan sosial yang rendah (G. M.A. Lodder et al., 2016), berpotensi menjadi korban bullying dan cyberbullying (Acquah et al., 2016; Olenik-Shemesh et al., 2012), kesuksesan akademik yang rendah (Benner, 2011) dan rendahnya kepuasan hidup (Salimi, 2011)

Mahasiswa tahun pertama adalah mahasiswa yang berada pada fase usia remaja. Masa remaja merupakan usia dimana terjadi perubahan yang signifikan pada aspek biologis, kognitif dan sosioemosional. Salah satu faktor yang mempengaruhi kesepian pada remaja adalah kualitas pertemanan. Kualitas pertemanan adalah hubungan pertemanan yang berkualitas dari seseorang dengan orang yang dianggap sebagai teman baiknya (Olenik-Shemesh et al., 2012) (Bukowski et al., 1994). Kualitas pertemanan dengan teman sebaya yang rendah dapat memprediksi pengalaman kesepian pada remaja (Qualter et al., 2015), sebaliknya ketika pertemanan berjalan dengan baik maka potensi pengalaman kesepian pada remaja semakin berkurang (Woodhouse et al., 2012). Remaja yang kesepian biasanya sedikit memiliki teman dan menarik diri dari kelompok teman sebaya (Wedaloka \& Turnip, 2019). Seseorang yang kesepian memiliki defisit dalam hubungan interpersonal. Hal ini didukung oleh hasil penelitian yang dilakukan oleh Buote et al (2007) menyatakan bahwa kualitas pertemanan dengan teman-teman baru memberikan dampak positif terhadap penyesuaian diri di lingkungan universitas, semakin mahasiswa tahun pertama memiliki kualitas pertemanan yang 
baik dengan teman-teman barunya maka semaikin bagus penyesuaian dirinya dengan lingkunga kampus sehingga diharapkan dapat menurunkan potensi mengalami kesepian.

Sifat kepribadian adalah salah satu prediktor kesepian yang dialami oleh seseorang (Uruk \& Demir, 2003). Hasil penelitian terdahulu mengungkapkan bahwa terdapat korelasi antara kesepian dengan sifat kepribadian. Sifat kepribadian ekstraversion dan agreableness berkorelasi negatif dengan kesepian, sifat kepribadian neurotik dan psikotik berkorelasi positif dengan kesepian (Atak, 2009; Nayyar \& Singh, 2011) dan sifat kepribadian openness, agreeableness dan conscientiousness berkorelasi negatif dengan kesepian (Panda, 2016). Hardiness adalah salah satu sifat kepribadian. Kobassa (Klag \& Bradley, 2004) mendefinisikan Hardiness sebagai kumpulan karakteristik kepribadian yang memiliki fungsi sebagai suatu sumber kekuatan dalam menghadapi peristiwa yang penuh tekanan.

Seseorang yang memiliki sifat kepribadian hardiness adalah orang yang mencoba terlibat aktif dan mempengaruhi seluruh kejadian dalam kehidupannya, memiliki keyakinan yang kuat dapat mencapai sesuatu yang diinginkan dan meyakini segala kesulitan sebagai sebuah pelajaran dan tantangan yang harus diatasi ( $\mathrm{Ng} \&$ Lee, 2020). Kesepian melibatkan dimensi kognitif, orang yang kesepian mempersepsikan interkasinya dengan jaringan sosial tidak berlangsung sesuai dengan harapan. Seseorang yang memiliki sifat kepribadian hardiness, ia mampu mengubah persepsinya terhadap jaringan sosialnya menjadi melalui strategi coping yang dilakukannya. Ketika seseorang mendapatkan tekanan-tekanan dalam hidupnya yang berpotensi menyebabkan kesepian, orang yang memiliki sifat kepribadian hardiness, ia mengubah penilainnya terhadap tekanan tersebut menjadi sesuatu yang tidak mengancam dirinya dan ia yakin dapat mengatasi tekanan-tekanan tersebut (Hasel et al., 2011). Hal ini sejalan dengan penelitian yang dilakukan oleh Ng dan Lee (2020) bahwa sifat kepribadian hardiness memediasi hubungan tidak langsung antara persepsi terhadap kesepian dengan gejala-gejala depresi.

Berdasarkan uraian keterkaitan variabel sebelumnya peneliti berasumsi bahwa hardiness dan kualitas pertemanan dapat memprediksi perubahan pada kesepian remaja. Kesepian dapat dihindari jika seseorang remaja memiliki kepribadian hardiness dan mampu membangun relasi kualitas pertemanan yang baik selama tahun pertama perkuliahan. 
Penelitian ini juga mencoba menggekplorasi Keterkaitan antara sifat kepribadian hardiness dengan. Terdapat penelitian sebelumnya yang mencoba memprediksi kesepian dengan sifat kepribadian hardiness, dimana kesimpulan penelitian tersebut adalah sifat kepribadian hardiness memediasi hubungan langsung persepsi kesepian terhadap gejala-gejala depresi ( $\mathrm{Ng}$ \& Lee, 2020). Tetapi dalam penelitian ini subjek yang digunakan adalah orang tua yang berumur 60 tahun keatas bukan remaja, selain itu sifat kepribadian hardiness dalam penelitian ini ditempatkan sebagai variabel mediasi hubungan tidak langsung antara persepsi kesepian dengan gejala-gejala depresi. Jadi belum ada penelitian yang mencoba mengkorelasikan secara langsung antara sifat kepribadian hardiness dengan kesepian dan menggunakan subjek yang berusia remaja. Penelitian ini juga penting dilakukan dikarenakan penelitian-penelitian sebelumnya yang mengeksplorasi keterkaitan antara kepribadian dan kesepian berfokus pada sifat kepribadian big five yaitu extraversion, agreeableness, openness, conscientiousness dan neuroticism, sangat jarang penelitian-penelitian yang mengeksplorasi keterkaitan sifat kepribadian hardiness dengan kesepian. Penelitian ini juga menambah khazanah variasi dari variabel-variabel kepribadain yang terkait dengan kesepian

Tujuan penelitian ini adalah untuk mengetahui peran hardiness dan kualitas pertemanan secara bersama-sama dalam memprediksi perubahan pada kesepian remaja. Hipotesis mayor penelitian ini adalah hardiness dan kualitas pertemanan secara bersama-sama dapat memprediksi perubahan pada kesepian remaja dan hipotesis minor pada penelitian ini adalah secara parsial hardiness dan kualitas pertemanan dapat memprediksi perubahan kesepian pada remaja.

\section{Metode}

Penelitian ini menggunakan pendekatan kuantitatif dengan desain korelasional dan komparasi. Terdapat dua variabel bebas dan satu variabel terikat dalam penelitian ini. Variabel bebas pertama adalah sifat kerpibadian hardiness, variabel bebas kedua adalah kualitas pertemanan dan variabel terikatnya adalah kesepian. Tujuan penelitian ini adalah untuk melihat apakah hardiness dan kualitas pertemanan dapat memprediksi kesepian pada remaja, 
selain itu penelitian ini juga mencoba melihat apakah terdapat perbedaan gender diantara seluruh variabel yang diteliti.

Populasi dalam penelitian ini adalah seluruh mahasiswa tahun pertama di kota Banjarmasin. Teknik pengambilan subjek menggunakan simple random samping. Total subjek dalam penelitian ini berjumlah 333 mahasiswa tahun pertama $($ Laki-laki $=69$; Perempuan $=$ 264). Alat pengumpul data yang digunakan adalah self report yang terdiri dari tiga skala yang dikonstruksi oleh peneliti. Pertama, skala kesepian yang mengacu pada aspek kesepian dari xxxx yaitu dengan Cronbach's Alpha =0,813. Kedua, Skala sifat kepribadian hardiness yang disusun mengacu pada aspek dari xxxx dengan Cronbach's Alpha=0,891. Ketiga, skala kualitas pertemanan menggunakan skala dari penelitian yang dilakukan oleh Mufidah dan Fitriah (2020) dengan Cronbach's Alpha =0,868. Analisis data yang digunakan adalah analisis regresi berganda dan independent sample t-test dengan menggunakan software Jeffreys's Amazing Statistics Program (JASP).

\section{$\mathrm{H}$ a $\mathrm{s}$ i 1}

Pada bagian ini akan dijelaskan data-data penelitian dalam bentuk data demografis subjek, hasil analisis statistic deskriptif, uji asumsi dan pengujian hipotesis. Berikut hasil yang didapatkan :

\section{Deskripsi Subjek Penelitian}

Berikut disajikan deskripsi data demografis subjek penelitian yang terdiri dari gender, asal universitas dan usia.subjek

Tabel 1

Data Demografis Subjek Penelitian

\begin{tabular}{cccc}
\hline Data Demografis & Kategori & $\sum$ & $\%$ \\
\hline Gender & Laki-Laki & 69 & 20.72 \\
& Perempuan & 264 & 79.28 \\
\hline Total & & 333 & $100 \%$ \\
\hline Asal Universitas & Universitas Muhammadiyah Banjarmasin & 213 & 64 \\
& Universitas Islam Negeri Antasari Banjarmasin & 95 & 28.5 \\
& Universitas Lambung Mangkurat & 6 & 1.8 \\
& Universitas Islam Kalimantan Syeikh Arsyad Al- & 19 & 5.7 \\
\hline Total & Banjari (Uniska) & 333 & $100 \%$ \\
\hline
\end{tabular}




\begin{tabular}{cccc} 
Usia & 17 Tahun & 26 & 7.8 \\
& 18 Tahun & 148 & 44.5 \\
& 19 Tahun & 118 & 35.4 \\
& 20 Tahun & 41 & 12.3 \\
\hline Total & & 333 & $100 \%$ \\
\hline
\end{tabular}

Deskripsi Analisis Deskriptif

Tabel 2

Analisis Data Deskriptif

\begin{tabular}{cccc}
\hline Variabel & Statistik & Hipotetik & Empirik \\
\hline Hardiness & Nilai Minimal & 23 & 50 \\
& Nilai Maksimal & 115 & 114 \\
& Mean & 69 & 87.37 \\
& Std. Deviasi & 15.3 & 9.89 \\
\hline \multirow{2}{*}{ Kualitas Pertemanan } & Nilai Minimal & 32 & 80 \\
& Nilai Maksimal & 160 & 152 \\
& Mean & 96 & 114.79 \\
Kesepian & Std. Deviasi & 21.3 & 12.17 \\
& Nilai Minimal & 15 & 15 \\
& Nilai Maksimal & 75 & 59 \\
& Mean & 45 & 36.05 \\
& Std. Deviasi & 10 & 7.46 \\
\hline
\end{tabular}

Berdasarkan penghitungan skor hipotetik dan skor empirik dari data penelitian di atas (tabel 2) maka dapat diketahui gambaran dari masing-masing variabel. Tiap variabel dikategorikan menjadi 3 kategori, yaitu rendah, sedang, dan tinggi. Berikut hasil dari pengkategorian subjek penelitian:

Tabel 3

Kategorisasi Skor Subjek

\begin{tabular}{cccc}
\hline Variabel & Kategori & $\sum$ & $\%$ \\
\hline Hardiness & Rendah & 1 & 0.30 \\
& Sedang & 126 & 37.84 \\
& Tinggi & 206 & 61.86 \\
\hline Total & & 333 & 100 \\
\hline Kualitas Pertemanan & Rendah & 0 & 0.00 \\
& Sedang & 211 & 63.36
\end{tabular}




\begin{tabular}{cccc} 
& Tinggi & 122 & 36.64 \\
\hline Total & & 333 & 100 \\
\hline \multirow{2}{*}{ Kesepian } & Rendah & 141 & 42.34 \\
& Sedang & 190 & 57.06 \\
& Tinggi & 2 & 0.60 \\
\hline Total & & 333 & 100 \\
\hline
\end{tabular}

Berdasarkan pengkategorian subjek pada tabel 3 dapat diketahui bahwa skor subjek penelitian dalam variabel hardiness dan kualitas pertemanan berada dalam kategori sedang dan tinggi, sedangkan variabel kesepian berada dalam kategori rendah dan sedang.

\section{Uji Normalitas}

Uji normalitas adalah prasayarat dilakukannya uji statistic parametrik, analisis regresi linier berganda merupakan salah satu analisis statistic parametrik. Uji normalitas menghendaki bahwa data di setiap variabel penelitian memiliki distribusi penyebaran data yang normal. Untuk menguji asumsi normalitas digunakan metode visual dengan melihat grafik quantilequantile plots (Q-Q Plots) (Howell, 2010). Berikut visualisasi penyebaran data berdasarkan grafik Q-Q plots :

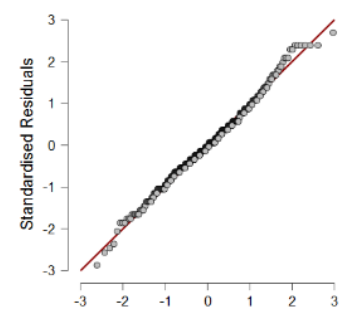

Hardiness

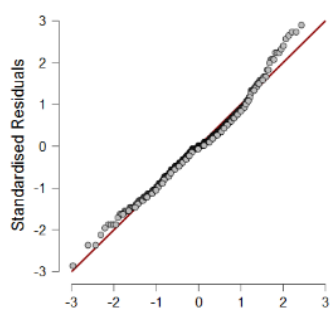

Kualitas Pertemanan

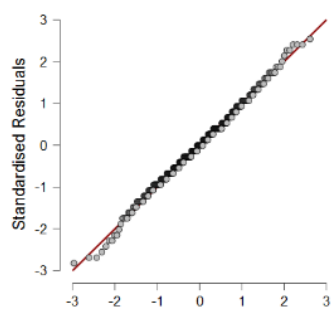

Kesepian

Berdasarkan kurva grafik Q-Q plot, data keseluruhan variabel berdistribusi normal dikarenakan titik-titik data penelitian menyebar di sepanjang garis lurus (Howell, 2010).

\section{Uji Korelasi dan Linieritas}

Pengujian korelasi dan regresi linier merupakan sebuah kesatuan yang tidak terpisah. Untuk menyimpulkan apakah perubahan variabel bebas dapat memprediksi perubahan pada variabel terikat melalui analisis regresi, maka sebelumnya dilakukan terlebih dahulu pengujian 
korelasi untuk mengetahui apakah keseluruhan variabel memiliki hubungan satu dengan yang lainnya. Analisis korelasi yang digunakan adalah korelasi Product-Moment Pearson, hasil pengujian korelasi ditunjukkan dalam tabel berikut :

Tabel 4

Analisis Korelasi

\begin{tabular}{|c|c|c|c|c|c|c|}
\hline & & Kesep & & Hardiness & & Kualitas Pertemanan \\
\hline \multirow{2}{*}{ Hardiness } & Pearson's r & -0.57 & $* * *$ & - & & \\
\hline & $\mathrm{p}$-value & $<.001$ & & - & & \\
\hline \multirow{2}{*}{ Kualitas Pertemanan } & Pearson's $r$ & -0.45 & $* * *$ & 0.43 & $* * *$ & - \\
\hline & p-value & $<.001$ & & $<.001$ & & - \\
\hline
\end{tabular}

${ }^{*} \mathrm{p}<.05,{ }^{* *} \mathrm{p}<.01,{ }^{* * *} \mathrm{p}<.001$

Tabel 4 diatas menunjukkan bahwa keseluruhan variabel memiliki hubungan yang signifikan, dimanan variabel hardines memiliki hubungan negatif dengan variabel kesepian $(r=$ - ,57; $\mathrm{p}<, 001)$, variabel kualitas pertemanan memiliki hubungan negatif dengan variabel kesepian $(r=-, 45 ; \mathrm{p}<, 001)$ dan variabel hardiness memiliki hubungan positif dengan variabel kualitas pertemanan $(r=, 43 ; \mathrm{p}<, 001)$. Hasil analisis korelasi ini juga dapat menunjukkan bahwa asumsi linieritas diantara keseluruhan variabel penelitian terpenuhi (Howel, 2010). Uji Multikolinieritas.

Uji multikolinieritas adalah salah satu prasyarat dalam uji regresi liniear berganda. Uji multikolinieritas menghendak keseluruhan variabel bebas atau variabel prediktor memiliki korelasi yang tidak terlalu tinggi. Multikolinieritas dapat dilihat melalui perhitungan nilai Tolerance dan VIF, jika nilai Tolerance lebih dari 0,1 dan nilai VIF kurang dari 10, maka dapat dikatakan bahwa tidak terjadi multikolinieritas dalam model regresi kita. Hasil pengujian multikolinieritas diantara variabel bebas dalam penelitian ini menunjukkan tidak ada terjadi kasus multikolinieritas model regresi dalam penelitian ini, ditunjukkan melalui nilai tolerance lebih dari 0,1 dan nilai VIF yang kurang dari 10 sebagai berikut: 
Tabel 5

Analisis Multikolinieritas

\begin{tabular}{|c|c|c|c|c|c|c|c|c|}
\hline \multirow{2}{*}{\multicolumn{2}{|c|}{ Model }} & \multirow[b]{2}{*}{ Unstandardized } & \multirow[b]{2}{*}{$\begin{array}{c}\text { Standard } \\
\text { Error }\end{array}$} & \multirow[b]{2}{*}{ Standardized } & \multirow[b]{2}{*}{$\mathbf{t}$} & \multirow[b]{2}{*}{ p } & \multicolumn{2}{|c|}{$\begin{array}{c}\text { Collinearity } \\
\text { Statistics }\end{array}$} \\
\hline & & & & & & & Tolerance & VIF \\
\hline \multirow[t]{3}{*}{1} & (Intercept) & 84.36 & 3.51 & & 24.05 & $<.001$ & & \\
\hline & Hardiness & -0.35 & 0.04 & -0.46 & -9.59 & $<.001$ & 0.81 & 1.23 \\
\hline & $\begin{array}{l}\text { Kualitas } \\
\text { Pertemanan }\end{array}$ & -0.16 & 0.03 & -0.25 & -5.28 & $<.001$ & 0.81 & 1.23 \\
\hline
\end{tabular}

\section{Uji Hipotesis}

Keseluruhan pengujian asumsi untuk membuat model regresi dalam penelitian ini terpenuhi sehingga dapat dilanjutkan ke tahap beriktunya yaitu pengujian regresi linier berganda. Uji hipotesis analisis regresi liniear berganda ditunjukkan oleh tabel 6, 7 dan 8, berikut adalah hasilnya :

Tabel 6

Uji Hipotesis Analisis Regresi Linear Berganda

\begin{tabular}{ccccc}
\hline Model & $\mathbf{R}$ & $\mathbf{R}^{\mathbf{2}}$ & Adjusted $\mathbf{R}^{\mathbf{2}}$ & RMSE \\
\hline 1 & 0.62 & 0.38 & 0.38 & 5.89 \\
\hline
\end{tabular}

Tabel 7

Uji Hipotesis Analisis Regresi Linear Berganda

\begin{tabular}{llllllr}
\hline Model & & \multicolumn{1}{c}{ Sum of Squares } & df & Mean Square & F & p \\
\hline 1 & Regression & 7018.67 & 2 & 3509.34 & 101.03 & $<.001$ \\
& Residual & 11462.56 & 330 & 34.74 & & \\
& Total & 18481.23 & 332 & & & \\
\hline
\end{tabular}

Tabel 6 dan 7 menunjukkan bahwa kedua variabel bebas secara bersama-sama yaitu hardiness dan kualitas pertemanan dapat memprediksi variabel terikat kesepian dengan signifikan, dimana hardiness dan kualitas pertemanan menjelaskan variasi kesepian sebesar 38 $\%\left(R^{2}=0,38 ; \mathrm{F}(2,330)=101,03 ; \mathrm{p}<, 001\right)$. 
Tabel 8

Uji Hipotesis Analisis Regresi Linear Berganda

\begin{tabular}{|c|c|c|c|c|c|c|c|c|}
\hline \multirow{2}{*}{\multicolumn{2}{|c|}{ Model }} & \multirow[b]{2}{*}{ Unstandardized } & \multirow[b]{2}{*}{$\begin{array}{c}\text { Standard } \\
\text { Error }\end{array}$} & \multirow[b]{2}{*}{ Standardized } & \multirow[b]{2}{*}{$\mathbf{t}$} & \multirow[b]{2}{*}{$\mathbf{P}$} & \multicolumn{2}{|c|}{$\begin{array}{c}\text { Collinearity } \\
\text { Statistics }\end{array}$} \\
\hline & & & & & & & Tolerance & VIF \\
\hline \multirow[t]{3}{*}{1} & (Intercept) & 84.36 & 3.51 & & 24.05 & $<.001$ & & \\
\hline & Hardiness & -0.35 & 0.04 & -0.46 & -9.59 & $<.001$ & 0.81 & 1.23 \\
\hline & $\begin{array}{l}\text { Kualitas } \\
\text { Pertemanan }\end{array}$ & -0.16 & 0.03 & -0.25 & -5.28 & $<.001$ & 0.81 & 1.23 \\
\hline
\end{tabular}

Berdasarkan tabel 8 juga dapat disimpulkan bahwa secara parsial setiap variabel bebas dapat memprediksi dengan signifikan perubahan variasi pada variabel terikat, dimana hardiness mampun memprediksi perubahan kesepian secara signifikan $(\mathrm{p}<, 001)$ dan kualitas pertemanan juga dapat memprediksi perubahan kesepian $(\mathrm{P}<, 001)$. Variasi perubahan kesepian yang dapat dijelaskan oleh hardiness sebesar 26,22 \% dan kualitas pertemanan sebesar 11,25\%. Dengan demikian hipotesis mayor yang menyatakan bahwa hardiness dapat memprediksi kesepian dan dan kualitas pertemanan dapat memprediksi kesepian diterima. Berdasarkan tabel 6, 7 dan 8, juga dapat dibuat garis persamaan regresi sebagai berikut:

Kesepian $=-0,35^{*}$ Hardiness $+-0,16^{*}$ Kualitas Pertemanan $+84,36$

Garis persamaan regresi ini menyatakan bahwa jika seseorang subjek tidak memiliki hardiness dan kualitas pertemanan maka skor kesepiannya adalah 84,36, sedangkan setiap satu poin kenaikan hardiness dapat menurunkan kesepian sebesar 0,35 dan setiap satu poin kenaikkan kualitas pertemanan dapat menurunkan kesepian sebesar 0,16.

\section{Analisis Tambahan}

Pada penelitian ini juga dimuat analisis tambahan untuk menjawab hipotesis minor yang diajukan. Hipotesis minor yang diungkap adalah terdapat perbedaan hardiness, kualitas 
pertemanan dan kesepian pada mahasiswa tahun pertama ditinjau dari jenis kelamin. Berikut adalah tabel hasil analisis uji perbedaan :

Tabel 9

Uji Perbedaan

\begin{tabular}{cc}
\hline Variabel & Signifikansi \\
\hline Hardiness & $\mathrm{P}>, 001$ \\
Kualitas Pertemanan & $\mathrm{P}>, 002$ \\
Kesepian & $\mathrm{P}>, 003$ \\
\hline
\end{tabular}

Berdasarkan tabel 9 dapat disimpulkan bahwa Hipotesis minor yang menyatakan terdapat perbedaan hardiness, kualitas pertemanan dan kesepian pada mahasiswa tahun pertama ditinjau dari jenis kelamin ditolak $(\mathrm{P}>, 001)$.

\section{Pembahasan}

Hasil penelitian menunjukkan bahwa kedua variabel bebas secara bersama-sama yaitu hardiness dan kualitas pertemanan dapat memprediksi variabel terikat kesepian dengan signifikan, dimana hardiness dan kualitas pertemanan menjelaskan variasi kesepian sebesar 38 $\%\left(\mathrm{R}^{2}=0,38 ; \mathrm{F}(2,330)=101,03 ; \mathrm{p}<, 001\right)$ dan secara parsial setiap variabel bebas dapat memprediksi dengan signifikan perubahan variasi pada variabel terikat, dimana hardiness mampun memprediksi perubahan kesepian secara signifikan $(\mathrm{p}<, 001)$ dan kualitas pertemanan juga dapat memprediksi perubahan kesepian $(\mathrm{P}<, 001)$. Variasi perubahan kesepian yang dapat dijelaskan oleh hardiness sebesar 26,22 \% dan kualitas pertemanan sebesar 11,25 \%. Dengan demikian hipotesis mayor yang menyatakan bahwa hardiness dapat memprediksi kesepian dan dan kualitas pertemanan dapat memprediksi kesepian diterima dengan prosentase kemampuan prediksi kedua variabel tersebut sebesar $38 \%$.

Hasil penelitian ini sejalan dengan temuan penelitian terdahulu tentang keterkaitan antara hardiness, kualitas pertemanan dengan kesepian. Penelitian yang dilakukan oleh Thomas et al., (2020) menemukan bahwa mahasiswa tahun pertama yang berhasil membentuk hubungan dekat dengan komunitas mahasiswa lain dengan cara terlibat aktif dalam aktivitas di kampus dan mencoba berinteraksi dengan orang-orang baru di komunitasnya tidak berpotensi 
mengalami kesepian, sebaliknya jika mereka tidak dapat membentuk hubungan dekat melalui keterlibatan tersebut cenderung berpotensi mengalami kesepian. Temuan Thomas et al., (2020) ini dapat dijelaskan melalui dua dimensi penyusun kesepian yaitu dimensi emosional dan social (Rönkä et al., 2014). Kesepian emosional terjadi ketika seseorang tidak memiliki sosok yang signifikan atau orang dekat dimana ia memiliki ikatan emosioanl dengan orang tersebut seperti teman dekat atau pasangan, sementara kesepian sosial terjadi ketika seseorang tidak memiliki teman atau kenalan dalam sebuah jaringan sosial seperti teman kerja dikantor dan tetangga di lingkungan sekitar rumah (Wedaloka \& Turnip, 2019). Pada penelitian ini yang dimaksud dengan jaringan sosial adalah jaringan komunitas mahasiswa di universitas.

Tahun pertama perkuliahan merupakan masa transisi perubahan rasa keterhubungan dan keamanan yang telah didapatkan dari keluarga dan komunitas mereka sebelumnya menjadi kebutuhan membangun keterhubungan dan identitas di lingkungan baru (Asher \& Weeks, 2013). Jauh dari orangtua, tanggung jawab terhadap sistem akademik baru, mencari teman, sahabat dan menemukan cara untuk menjadi anggota di lingkungan baru adalah beberapa tantangan dan kesulitan yang harus di hadapi oleh mahasiswa tahun pertama(Asher \& Weeks, 2013; Hicks \& Heastie, 2008; Smith \& Wertlieb, 2011). Mahasiswa yang berhasil melewati kesulitan dan tantangan tersebut mengembangkan keterampilan, kompetensi dan pengetahuan diri yang berguna untuk membantu mereka melakukan penyesuaian pada masa transisi ini (Asher \& Weeks, 2013), sebaliknya ketika mereka tidak mampu menghadapinya maka dapat memicu pengalaman kesepian pada diri mereka (Lou et al., 2012).

Pengalaman kesepian yang dialami oleh mahasiswa tahun pertama selain diprediksi oleh keberhasilan membentuk hubungan dekat dengan komunitas yang diperlukan tetapi juga dibutuhkan kemampuan untuk mempertahankan relasi yang baik sepanjang satu tahun pertama perkuliahan dengan komunitasnya (Oswald \& Clark, 2003). Kemampuan mempertahankan relasi yang baik sepanjang satu tahun pertama dengan komunitas dapat meminimaisir kesulitan yang berpotensi menyebabkan kesepian pada tahun pertama. Hal ini sesuai dengan penjelasan yang dikemukakan oleh Oswald dan Clark (2003), yang menyatakan bahwa manfaat dari mempertahankan relasi yang baik dengan teman adalah membantu melakukan penyesuaian diri dan meningkatkan kualitas pertemanan diantara mereka. Buote et 
al (2007) menyatakan bahwa kualitas pertemanan dengan teman-teman baru memberikan dampak positif terhadap penyesuaian diri di lingkungan universitas, semakin mahasiswa tahun pertama memiliki kualitas pertemanan yang baik dengan teman-teman barunya maka semaikin bagus penyesuaian dirinya dengan lingkunga kampus sehingga diharapkan dapat menurunkan potensi mengalami kesepian. Kemampuan mempertahankan relasi yang baik juga bisa dipahami sebagai kemampuan meminimalisir hal-hal negatif yang terjadi pada saat membangun hubungan relasi dengan komunitas, ketika mahasiswa tahun pertama mampu meminimalisir hal-hal negatif dalam hubungan pertemanan mereka, maka potensi mengalami kesepian dapat berkurang (Vanhalst et al., 2014).

Mahasiswa tahun pertema adalah mereka yang berada dalam fase usia remaja. Sebuah temuan menarik menunjukkan keterakitan antara kualitas pertemanan dengan kesepian yang dialami oleh remaja. Lodder et al. (2017) menemukn bahwa kesepian yang dialami oleh seorang remaja disebabkan karena persepsi yang mereka laporkan terkait dengan kualitas pertemanan yang mereka bangun. Mereka membangun standar persepsi yang tinggi terkait dengan kualitas pertemanan yang seharusnya dirasakan dibandingkan standar persepsi yang dibangun oleh teman-temannya. Kesepian yang mereka alami dan kualitas pertemanan yang rendah hanya terjadi pada diri mereka sendiri namun tidak pada teman-temannya (Lodder et al., 2017). Selain itu, Penelitian yang dilakukan oleh Nicolaisen dan Thorsen (2017) memperkuat temuan yang dihasilkan dalam penelitian ini, bahwa kualitas pertemanan berperan penting dalam mereduksi kesepian yang dialami oleh seseorang. Nicolaisen dan Thorsen (2017) menunjukkan bahwa kualitas pertemanan dapat menetukan potensi kesepian yang dialami seseorang di seluruh fase kehidupan manusia. Penelitan ini menemukan bahwa pada kelompok usia muda (18-29 tahun), potensi kesepian diakibatkan oleh kurangnya frekuensi kontak dengan teman, pada kelompok usia menengah (30-49 dan 50-64 tahun) potensi kesepian disebabkan semakin sedikitnya teman dekat dan kurangnya frekuensi kontak dengan mereka dan pada kelompok usia tua (65-79 tahun), potensi kesepian disebabkan karena tidak ada kontak dengan teman dan semakin berkurangnya interaksi dengan teman dekat (Nicolaisen \& Thorsen, 2017). Penelitian ini menguatkan bahwa kualitas pertemanan yang bagus baik dari sisi kuantitatif dan kualitatif berperan penting dalam meminimalisir kesepian yang terjadi pada individu. 
Kualitas pertemana merupakan faktor external yang dapat memprediksi kesepian, tetapi tidak hanya faktor external, faktor internal juga berperan penting dalam memprediksi kesepian pada mahasiswa tahun pertama. Vanhalst et al. (2014) menemukan bahwa faktor internal dapat mempengaruhi kesepian pada remaja, mereka menemukan bahwa harga diri yang rendah dan perasaan malu yang dimiliki oleh remaja dapat membuat mereka mengalami kesepian. Sifat kepribadian hardiness adalah salah satu atribut internal yang dimiliki oleh seseorang. Penelitian yang dilakukan oleh Vanhalst et al. (2014) selaras dengan temuan yang dihasilkan dalam penelitian ini, dimana sifat kepribadian hardiness, baik secara bersama-sama dengan kualitas pertemanan maupun secara parsial dapat memprediksi kesepian pada mahasiswa tahun pertama.

Sifat kepribadian hardiness merupakan bentuk sifat kepribadian positif yang ada dalam diri individu. Sifat kepribadian hardiness merupakan sebuah konsep kepribadian yang memiliki tiga karakteristik yang saling berkaitan yaitu komitmen, kontrol dan tantangan (Klag \& Bradley, 2004). Seseorang yang memiliki sifat kepribadian hardiness adalah orang yang mencoba terlibat aktif dan mempengaruhi seluruh kejadian dalam kehidupannya, memiliki keyakinan yang kuat dapat mencapai sesuatu yang diinginkan dan meyakini segala kesulitan sebagai sebuah pelajaran dan tantangan yang harus diatasi ( $\mathrm{Ng}$ \& Lee, 2020), sehingga jika mahasiswa tahun pertama memiliki sifat kepribadian hardiness maka ia akan mampu mengatasi kesulitan-kesulitan yang dihadapi nya selama tahun pertama perkuliahan. Mereka akan secara proaktif mengatasi kesulitanya dan pada akhirnya dapat mencegah potensi mengalami kesepian (Wang, 2017).

Kesepian melibatkan dimensi kognitif, orang yang kesepian mempersepsikan interkasinya dengan jaringan sosial tidak berlangsung sesuai dengan harapan. Seseorang yang memiliki sifat kepribadian hardiness, ia mampu mengubah persepsinya terhadap jaringan sosialnya menjadi melalui strategi coping yang dilakukannya. Ketika seseorang mendapatkan tekanan-tekanan dalam hidupnya yang berpotensi menyebabkan kesepian, orang yang memiliki sifat kepribadian hardiness, ia mengubah penilainnya terhadap tekanan tersebut menjadi sesuatu yang tidak mengancam dirinya dan ia yakin dapat mengatasi tekanan-tekanan 
tersebut (Hasel et al., 2011). Individu yang memiliki sifat kepribadian hardiness merasa bahagia dan puas dengan kehidupannya (Dabaghi \& Moghaddam, 2016).

\section{Kesimpulan}

Pengujian hipotesis regresi linier berganda menunjukkan bahwa secara bersama-sama hardiness dan kualitas pertemanan dapat memprediksi kesepian pada remaja dengan variasi yang dijelaskan oleh keduanya sebesar 38\% ( $\left.F=101,03 ; p<, 001 ; R^{2}=, 38\right)$. Secara parsial hardiness dapat memprediksi kesepian dengan variasi sebesar 26,22\% demikian juga kualitas pertemanan signifikan memprediksi kesepian dengan variasi sebesar $11,25 \%\left(R^{2}=, 1125\right.$; $\mathrm{p}<$ ,001).

Saran

Dapat disimpulkan bahwa kesepian dapat dihindari jika seseorang remaja memiliki siat kepribadian hardiness dan mampu membangun relasi kualitas pertemanan yang baik selama tahun pertama perkuliahannya.

\section{Referensi}

Acquah, E. O., Topalli, P. Z., Wilson, M. L., Junttila, N., \& Niemi, P. M. (2016). Adolescent Loneliness and Social Anxiety as Predictors of Bullying Victimisation. International Journal of Adolescence and Youth, 21(3), 320-331.

Asher, S. R., \& Weeks, M. S. (2013). Loneliness and Belongingness in the College Years. The Handbook of Solitude, 283-301.

Atak, H. (2009). Big Five Traits and Loneliness Among Turkish Emerging Adults. Cognitive, $\begin{array}{llll}\text { Educational and Psychological 124-128. } & \text { Sciences, }\end{array}$ https://www.researchgate.net/publication/277021068

Benner, A. D. (2011). Latino Adolescents' Loneliness, Academic Performance, and the Buffering Nature of Friendships. Journal of Youth and Adolescence, 40(5), 556-567.

Buote, Vanessa M; Pancer, S Mark; Prat, Michael W; Adams, Gerarld; Birnie-lefcovitch, Shelly; Polivu, Janet; Wintre, M. G. (2007). The Importance of Friends. Journal of Adolescent Research, 22(6), 665-689.

Dabaghi, M. F., \& Moghaddam, H. S. (2016). International Research Journal of Pharmaceutical and Applied Sciences ( IRJPAS ) A Survey on the Relationship between Psychological Hardiness and' Happiness and Feeling of Loneliness ' among the Elderly Living in Nursing home in Tehran. 6(2).

Fikrie, L. A., \& Hermina, C. (n.d.). Perbedaan Kesepian pada Mahasiswa Tahun Pertama dan Kedua.

Hasel, K. M., Abdolhoseini, A., \& Ganji, P. (2011). Hardiness Training and Perceived Stress 
Among College Students. Procedia - Social and Behavioral Sciences, 30, 1354-1358.

Hicks, T., \& Heastie, S. (2008). High School to College Transition: A Profile of The Stressors, Physical and Psychological Health Issues That Affect The First-Year On-Campus College Student. Journal of Cultural Diversity, 15(3), 143-147.

Kapıkıran, Ş. (2013). Loneliness and Life Satisfaction in Turkish Early Adolescents: The Mediating Role of Self Esteem and Social Support. Social Indicators Research, 111(2), 617632.

Klag, S., \& Bradley, G. (2004). The Role of Hardiness In Stress and Illness: An exploration of The Effect of Negative Affectivity and Gender. British Journal of Health Psychology, 9(2), 137-161.

Lodder, G. M.A., Goossens, L., Scholte, R. H. J., Engels, R. C. M. E., \& Verhagen, M. (2016). Adolescent Loneliness and Social Skills: Agreement and Discrepancies Between Self-, Meta-, and Peer-Evaluations. Journal of Youth and Adolescence, 45(12), 2406-2416.

Lodder, Gerine M.A., Scholte, R. H. J., Goossens, L., \& Verhagen, M. (2017). Loneliness in Early Adolescence: Friendship Quantity, Friendship Quality, and Dyadic Processes. Journal of Clinical Child and Adolescent Psychology, 46(5), 709-720.

Lou, L. L., Yan, Z., Nickerson, A., \& McMorris, R. (2012). An Examination of The Reciprocal Relationship of Loneliness and Facebook Use Among First-Year College Students. Journal of Educational Computing Research, 46(1), 105-117.

Mufidah, G., \& Fitriah, A. (2020). Pemaafan dan Kualitas Persahabatan Pada Remaja Forgiveness and the Quality of Friendship in Adolescents. 2(2).

Nayyar, S., \& Singh, B. (2011). Personality Correlates of Loneliness. Journal of the Indian Academy of Applied Psychology, 37, 163-168.

Ng, S. M., \& Lee, T. M. C. (2020). The Mediating Role of Hardiness in The Relationship Between Perceived Loneliness and Depressive Symptoms Among Older. Aging and Mental Health, 24(5), 805-810.

Nicolaisen, M., \& Thorsen, K. (2017). What Are Friends for? Friendships and Loneliness Over the Lifespan - From 18 to 79 Years. International Journal of Aging and Human Development, 84(2), 126-158.

Olenik-Shemesh, D., Heiman, T., \& Eden, S. (2012). Cyberbullying Victimisation in Adolescence: Relationships With Loneliness and Depressive Mood. Emotional and Behavioural Difficulties, 17(3-4), 361-374.

Oswald, D. L., \& Clark, E. M. (2003). Best Friends Forever?: High school Best Friendships and The Transition to College. Personal Relationships, 10(2), 187-196.

Panda, S. (2016). Personality Traits and The Feeling of Loneliness of Post-Graduate. The International Journal of Indian Psychology ISSN, 3005(31), 2348-5396.

Qualter, P., Vanhalst, J., Harris, R., Van Roekel, E., Lodder, G., Bangee, M., Maes, M., \& Verhagen, M. (2015). Loneliness Across the Life Span. Perspectives on Psychological Science, 10(2), 250-264.

Rönkä, A. R., Rautio, A., Koiranen, M., Sunnari, V., \& Taanila, A. (2014). Experience of Loneliness Among Adolescent Girls and Boys: Northern Finland Birth Cohort 1986 study. Journal of Youth Studies, 17(2), 183-203.

Salimi, A. (2011). Social-Emotional Loneliness and Life Satisfaction. Procedia - Social and Behavioral Sciences, 29(2010), 292-295. 
Smith, J. S., \& Wertlieb, E. C. (2011). Do First-Year College Students' Expectations Align with their First-Year Experiences? Journal of Student Affairs Research and Practice, 42(2), 153-174.

Thomas, L., Orme, E., \& Kerrigan, F. (2020). Student Loneliness: The Role of Social Media Through Life Transitions. Computers and Education, 146(September 2019), 103754.

Uruk, A. C., \& Demir, A. (2003). The Role of Peers and Families in Predicting The Loneliness Level of Adolescents. Journal of Psychology: Interdisciplinary and Applied, 137(2), 179-193.

Vanhalst, J., Luyckx, K., \& Goossens, L. (2014). Experiencing Loneliness in Adolescence: A Matter of Individual Characteristics, Negative Peer Experiences, or Both? Social Development, 23(1),

Wang, L. (2017). The Relationship Between Interpersonal Trust and Loneliness of University Students: The Mediating Role of Personality Hardiness. 93(Cetcu), 77-80.

Wedaloka, K. B., \& Turnip, S. S. (2019). Gender Differences In The Experience of Loneliness Among Adolescents in Jakarta. HUMANITAS: Indonesian Psychological Journal, 16(1), 33.

Wols, A., Scholte, R. H. J., \& Qualter, P. (2015). Prospective Associations Between Loneliness and Emotional Intelligence. Journal of Adolescence, 39, 40-48.

Woodhouse, S. S., Dykas, M. J., \& Cassidy, J. (2012). Loneliness and Peer Relations in Adolescence. Social Development, 21(2), 273-293. x

\begin{tabular}{|l|l|l|l|l|}
\hline Submit & Review & Revisi & Diterima & Publis \\
\hline $10-12-2020$ & 26-03-2021 sd 03-04-2021 & 21-04-2021 & 24-04-2021 & $13-06-2021$ \\
\hline
\end{tabular}

Fikrie, Ceria Hermina, Lita Ariani

Universitas Muhammadiyah Banjarmasin

Email : fikrielutfiyah@gmail.com, ceria.hermina@gmail.com, arianilita87@gmail.com 